\title{
Benchmarks
}

Spring Harbor, NY.

7.Winocour, E., L. Puzis, S. Etkin, T. Koch, B. Danovitch, E. Mendelson, E. Shaulian, S. Karby and S. Lavi. 1992. Modulation of cellular phenotype by integrated adeno associated virus. Virology 190:316-329.

8.Zon, L.I., D.M. Dorfman and S.H. Orkin. 1989. The polymerase chain reaction colony miniprep. BioTechniques 7:696-698.

Address correspondence to Sara Lavi, Department of Cell Research and Immunology, George S. Wise Faculty of Life Sciences, Tel Aviv University, Tel Aviv 69978, Israel.Internet: sara@life.tau.ac.il

Received 4 November 1996; accepted 28 February 1997.

Sigal Gery and Sara Lavi

Tel Aviv University

Tel Aviv, Israel

\section{PCR Synthesis of cDNA from Total RNA}

BioTechniques 23:202-204 (August 1997)

Until recently, the synthesis of highquality cDNA was only possible using poly $(\mathrm{A})^{+}$RNA. Unfortunately, the amount of RNA that can be isolated from many tissues and other biological samples is often limiting, precluding use of standard cDNA synthesis techniques. Previous reports detailed protocols to synthesize cDNA from total RNA, but these methods often involve laborious techniques and produce libraries with inserts that are relatively small (400-800 bp) $(1,2,3)$.

Perhaps the most challenging step in polymerase chain reaction (PCR) cDNA synthesis is the addition of a specific sequence tag to the $5^{\prime}$ end of the cDNA that is suitable for subsequent cDNA PCR amplification. The addition of a homopolymeric tail using terminal deoxyribonucleotidyl transferase (TdT) is the most widely used method for incorporating a known primer-binding sequence. However, cDNAs containing oligo(dA) or oligo(dT) tails are not good substrates for PCR because primers that bind to the homopolymer- ic tracts anneal at low temperatures and often bind DNA nonspecifically. Similarly, primers that bind oligo(dG) or oligo(dC) tracts also bind nonspecifically during amplification because PCR is performed at temperatures well below the primer melting temperature. Modified primers containing mixtures of deoxyguanosine and deoxyinosine bases reduce primer GC content and melting temperature and can increase specificity (5). We demonstrate that using DNA polymerase preparations that contain proofreading activities for both secondstrand synthesis and cDNA amplification enables the incorporation of a defined primer sequence into the $5^{\prime} \mathrm{cDNA}$ end and the specific production of 500-2000-bp cDNAs.

To synthesize cDNA, we annealed an adaptor primer that had a $5^{\prime}$-specific binding sequence to oligo(dA)-tailed first-strand cDNA and extended the second strand using rTth XL DNA Polymerase (Perkin-Elmer, Norwalk, CT, USA) to produce double-stranded
cDNA (Figure 1). Since the same primer was also used to initiate firststrand synthesis, the resultant cDNA population contained identical primerbinding sequences on both $5^{\prime}$ and $3^{\prime}$ ends. Purified double-stranded cDNA was specifically amplified using a primer that recognizes the heteropolymeric adaptor sequence.

To demonstrate cDNA synthesis, we produced amplified cDNA populations using total RNA derived from a surgical biopsy tissue specimen. Total RNA was isolated from a human breast tumor using the RNeasy ${ }^{\circledR}$ Total RNA Isolation System (Qiagen, Chatsworth, CA, USA) following the manufacturer's instructions. RNA yield and quality were determined using a DU ${ }^{\circledR}$ Series 650 Spectrophotometer (Beckman Instruments, Fullerton, CA, USA) and by agarose gel electrophoresis of an RNA aliquot in a standard formaldehyde gel (4). One microgram of total RNA was DNase-treated in a $10-\mu \mathrm{L}$ reaction mixture as described by the manufacturer

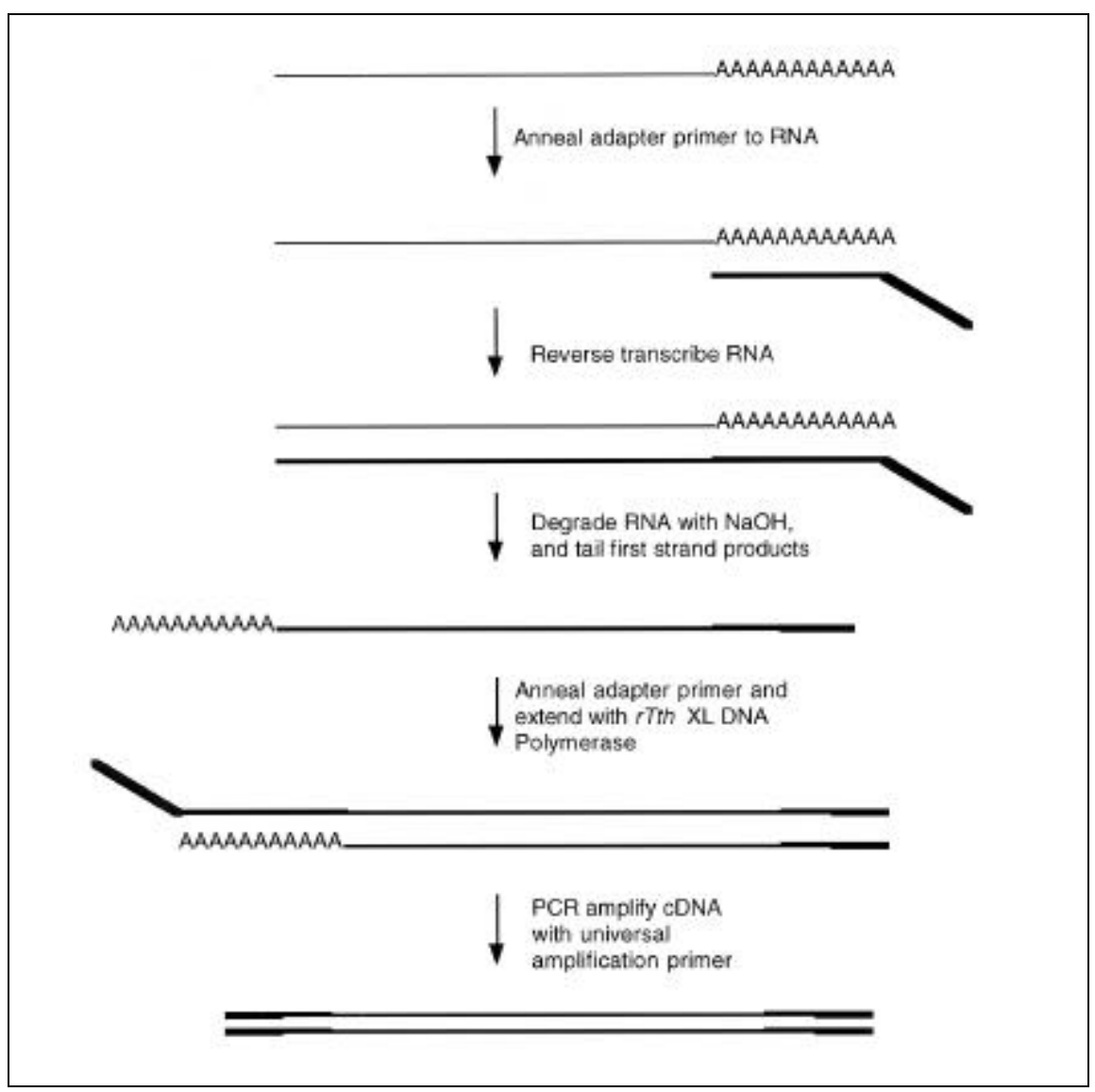

Figure 1. Diagram of cDNA synthesis technique by PCR. The steps used to amplify whole cDNA from total RNA are shown. 
(Life Technologies, Gaithersburg, MD, USA). DNase-treated RNA was then reverse-transcribed in a $20-\mu \mathrm{L}$ reaction mixture containing $50 \mathrm{mM}$ Tris- $\mathrm{HCl}$, $\mathrm{pH} 8.3,75 \mathrm{mM}$ KCL, $3 \mathrm{mM} \mathrm{MgCl} 2,10$ $\mathrm{mM}$ dithiothreitol (DTT), $200 \mathrm{U}$ SUPERSCRIPT ${ }^{\mathrm{TM}}$ II (Life Technologies), 10 pmol adaptor primer [5'-GGCCACGCGTCGACTAGTAC( $\left.\mathrm{T}_{17}\right)-3^{\prime}$; Life Technologies] at $42^{\circ} \mathrm{C}$ for $60 \mathrm{~min}$, then at $70^{\circ} \mathrm{C}$ for $15 \mathrm{~min}$. All temperature incubations were performed in a GeneAmp ${ }^{\circledR}$ PCR System 9600 Thermal Cycler (Perkin-Elmer). Freshly prepared $5 \mathrm{M} \mathrm{NaOH}(2.5 \mu \mathrm{L})$ was added and the reaction incubated at $55^{\circ} \mathrm{C}$ for $30 \mathrm{~min}$. After the addition of $72 \mu \mathrm{L}$ of $1 \%$ acetic acid, the first-strand reaction mixture was purified using QIAquick ${ }^{\mathrm{TM}}$ PCR Spin Columns as described by the manufacturer (Qiagen). Purified firststrand cDNA $(18.75 \mu \mathrm{L})$ was dA-tailed in a reaction mixture containing $20 \mathrm{mM}$ Tris-HCl, pH 8.4, $50 \mathrm{mM} \mathrm{KCl,} 1.5 \mathrm{mM}$ $\mathrm{MgCl}_{2}, 0.2 \mathrm{mM}$ dATP, $10 \mathrm{U}$ TdT (Life Technologies) at $37^{\circ} \mathrm{C}$ for $10 \mathrm{~min}$. The reaction was terminated by incubation at $65^{\circ} \mathrm{C}$ for $10 \mathrm{~min}$ and purified using QIAquick columns. Tailed first-strand cDNA $(20 \mu \mathrm{L})$ was converted to double-stranded cDNA in a 50- $\mu \mathrm{L}$ hot-start reaction mixture $[1 \times \mathrm{XL}$ buffer, $0.8 \mathrm{mM}$ $\mathrm{Mg}(\mathrm{OAc})_{2}, 0.15 \mathrm{mM}$ dNTPs, $10 \mathrm{pmol}$ adaptor primer] using a single-cycle temperature profile of $94^{\circ} \mathrm{C}$ for $20 \mathrm{~s}$, $80^{\circ} \mathrm{C}$ for $30 \mathrm{~s}, 36^{\circ} \mathrm{C}$ for $30 \mathrm{~s}, 1-\mathrm{min}$ ramp to $70^{\circ} \mathrm{C}, 70^{\circ} \mathrm{C}$ for $15 \mathrm{~min}$. rTth XL DNA polymerase $(2.0 \mathrm{U})$ was added during the 30 -s hold at $80^{\circ} \mathrm{C}$. The reaction mixture was purified using QIAquick columns and eluted into 50 $\mu \mathrm{L}$ of water. Whole cDNA was ampli-

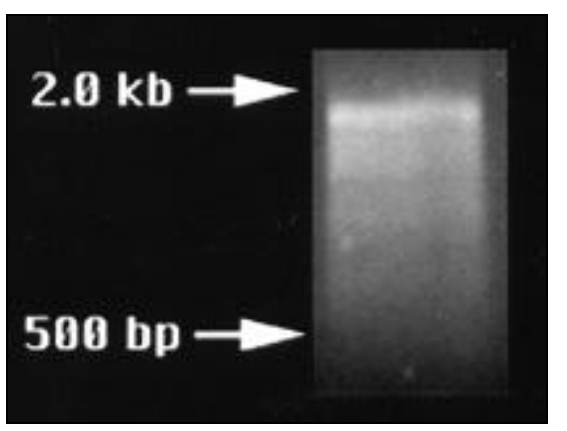

Figure 2. cDNA amplification products. One tenth of the cDNA PCR amplification mixture was subjected to agarose gel electrophoresis and visualized by ethidium bromide staining. Lengths of cDNA products are as indicated. fied in a $100-\mu \mathrm{L}$ reaction mixture $[1 \times$ XL buffer, $0.6 \mathrm{mM} \mathrm{Mg}(\mathrm{OAc})_{2}, 0.10$ mM dNTPs, 20 pmol universal amplification primer (5'-GGCCACGCGTCGACTAGTAC-3'; Life Technologies), 10 $\mu \mathrm{L}$ purified double-stranded cDNA, 4.0 $\mathrm{U}$ rTth XL DNA polymerase] using a temperature profile of $94^{\circ} \mathrm{C}$ for $20 \mathrm{~s}$, $68.5^{\circ} \mathrm{C}$ for $4 \mathrm{~min} 30 \mathrm{~s}$ for 16 cycles, then $94^{\circ} \mathrm{C}$ for $20 \mathrm{~s}, 68.5^{\circ} \mathrm{C}$ for $4 \mathrm{~min} 30$ $\mathrm{s}$ with a 5-s auto segment extension for 19 cycles. cDNA $(10 \mu \mathrm{L})$ was subjected to agarose gel electrophoresis for 30 $\min$ at $150 \mathrm{~V}$ and visualized by ethidium bromide staining (Figure 2). We routinely produced $2 \mu \mathrm{g}$ of cDNA, ranging in length from 500-2000 bp, from each PCR (average size is about 1000-1300 bp). Since we use only a portion of the first- and second-strand reaction mixtures, the potential exists to synthesize $50 \mu \mathrm{g}$ of cDNA from the initial $1 \mu \mathrm{g}$ of total RNA. We have also successfully used this method to synthesize cDNA from poly(A) ${ }^{+}$mRNA.

Ligating amplified cDNA into plasmid or phage vectors is easily accomplished since the adaptor primer contains a SalI restriction enzyme site. Primers containing other restriction enzyme cleavage sites can also be used successfully (data not shown). Alternatively, cDNA preparations from normal and diseased tissues and cell lines can be used directly in subtractive hybridization procedures to identify differentially expressed genes. Since this procedure uses thermostable polymerases with proofreading capabilities, it offers a simple and attractive alternative to standard cDNA synthesis techniques.

\section{REFERENCES}

1.Belyavsky, A., T. Vinogradova and K. Rajewsky. 1989. PCR-based cDNA library construction: general cDNA libraries at the level of a few cells. Nucleic Acids Res. 17:29192932.

2.Belyavsky, A., T. Vinogradova and K. Rajewski. 1989. PCR-based cDNA library construction: general cDNA libraries at the level of a few cells. Nucleic Acids Res. 17:5833. Erratum.

3.Domec, C., B. Garbay, M. Fournier and J. Bonnet. 1990. cDNA library construction from small amounts of unfractionated RNA: association of cDNA synthesis with polymerase chain reaction amplification. Anal. Biochem. 188:422-426.

4.Sambrook, J., E.F. Fritsch and T. Maniatis.
1989. Molecular Cloning: A Laboratory Manual, 2nd ed. CSH Laboratory Press, Cold Spring Harbor, NY.

5.Schuster, D.M., G.W. Buchman and A. Rashtchian. 1992. A simple and efficient method for amplification of cDNA ends using 5'RACE. Focus 14:46-52.

This work was supported in part by a grant from the Massachusetts Department of Public Health. Address correspondence to Scott B. Shepard, Pathology Department, Faulkner Hospital, 1153 Centre St., Jamaica Plain, MA 02130, USA. Internet: sshepard@tiac.net

Received 8 October 1996; accepted 28 February 1997.

\author{
Scott B. Shepard and Amiel \\ G. Cooper \\ Faulkner Hospital \\ Jamaica Plain, MA, USA
}

\section{Pitfalls of PCR: Cross- Reactivity with Joyride E. coli Nucleic Acid}

BioTechniques 23:204-206 (August 1997)

Polymerase chain reaction (PCR) is a powerful method for the primer-directed enzymatic synthesis of millions of copies of a specific DNA segment. This method is so sensitive that single DNA molecules can be detected. Reverse transcription (RT) followed by a PCR amplification (RT-PCR) provides a sensitive method for the detection and quantification of RNA. The use of intron-spanning primers has been shown to be an efficient way to distinguish between genomic and cDNA products. Due to the amplification capacity of PCR, contamination for a given sample, either with products of an earlier PCR or with exogenous DNA, can create false-positive results. We report a nonspecific amplification of joyride (i.e., contaminating) E. coli $23 \mathrm{~S}$ rRNA or DNA of exogenous origin with primers specific to the immediate-early 1 (IE1) gene of human cytomegalovirus (hCMV). Human fetal lung fibroblast 